\title{
Debt choice, growth opportunities and corporate investment: evidence from China
}

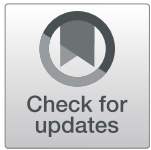

Ning Ding ${ }^{1}$, Kalimullah Bhat ${ }^{1 *}$ (D) and Khalil Jebran ${ }^{2}$

\author{
* Correspondence: bhat_dufe@ \\ outlook.com \\ ${ }^{1}$ School of Finance, Dongbei \\ University of Finance and \\ Economics, Dalian, China \\ Full list of author information is \\ available at the end of the article
}

\begin{abstract}
The study aims to investigate how relying on short-term debt may help Chinese listed firms to make efficient investment decisions and reduce overinvestment problem for low-growth firms. The study uses a large set of panel data of nonfinancial Chinese listed firms over the period 2007-2017 and, using the robust twostage generalized method of moments, which is robust to unobserved heterogeneity of individual firms and addresses endogeneity issues. Findings show a positive relationship between growth and investment; this association is enhanced by leverage, especially for high-growth firms. This supports the view that short-term debt helps Chinese firms to make optimal use of leverage and therefore make better investment decisions. Furthermore, the results reveal that leverage plays a disciplining and monitoring role to reduce overinvestment incentive for low-growth firms. Overall, the study suggests that shareholders should consider short-term debt to mitigate the debt overhang problem and restrict the opportunistic behavior of managers, which can lead to efficient investment decisions. It also provides foreign investors insights about capital structure in China, and how it can help them make better investment decisions.
\end{abstract}

Keywords: Chinese firms, Leverage, Growth, Investment

\section{Introduction}

The interaction of financing and investment decisions is a subject of considerable discussion in economic literature. Modigliani and Miller (1958) argue that, in a perfect capital market, both financing and investment decisions are not interdependent. However, theoretical and empirical literature relaxed perfect market assumptions, subsequent studies revealed how market frictions and imperfections cause interactions between financing and investment strategies. Myers (1977) argues that managers may give up some projects with positive net present values (NPVs) due to underinvestment problems. Dang (2011) suggests that short-term debt that expires before a new investment project, in anticipation of valuable growth opportunities, mitigates the debt overhang.

Adjusting future capital structure over time and under a static debt policy is very costly for firms. The costs that arise from investment deviations can lead firms to reduce their leverage and also may have no impact on debt maturity. However, adopting

(c) The Author(s). 2020 Open Access This article is licensed under a Creative Commons Attribution 4.0 International License, which permits use, sharing, adaptation, distribution and reproduction in any medium or format, as long as you give appropriate credit to the original author(s) and the source, provide a link to the Creative Commons licence, and indicate if changes were made. The images or other third party material in this article are included in the article's Creative Commons licence, unless indicated otherwise in a credit line to the material. If material is not included in the article's Creative Commons licence and your intended use is not permitted by statutory regulation or exceeds the permitted use, you will need to obtain permission directly from the copyright holder. To view a copy of this licence, visit http://creativecommons.org/licenses/by/4.0/. 
a dynamic debt policy gives firms financial flexibility and enables them to adjust their level of debt over time. Thus, short-term debt is usually considered optimal to mitigate sub-optimal investment decisions by repricing and renegotiating debt contracts.

Jensen (1986) and Stulz (1990) suggest that leverage can play a disciplining role in firms that have low growth opportunities with large free cash flows because it restricts managers from overinvesting in risky projects. In China, listed firms tend to rely more on short-term debt (Cai et al. 2008; Jiang et al. 2017) as compared with firms in western economies (Dang 2011). Moreover, the descriptive statistics of the current study reveal that the mean value of the short-term debt ratio (SDEBTRATIO) is 0.69, which suggests that short-term debt comprises approximately $69 \%$ of total debt in Chinese firms. Therefore, we expect that more short-term debt in Chinese listed firms help them to make better financing decisions and ultimately lead to efficient investment decisions.

Several studies, such as Aivazian et al. (2005b), argue that leverage has a negative association with investment. Myers (1977) suggests that, in highly levered firms with high-growth opportunities, managers may give up some investment projects having positive NPVs to protect shareholders' interests, which results in underinvestment problems. Moreover, Childs et al. (2005) suggest that short-term debt can mitigate underinvestment problems by making debt less sensitive to changes in firm value and by allowing for more frequent repricing of debt. In addition, Dang (2011) conducted a study in UK listed firms, reporting that leverage does not enhance the impact of growth on investment, which suggests that relying on more long-term debt does not help firms to make efficient investment decisions. Therefore, to the best of our knowledge, there remains a gap in this body of literature in consideration of whether relying on shortterm debt helps Chinese firms to make efficient investment decisions. As leverage consists of both short-term and long-term debt, and higher proportion of short-term debt can make Chinese firms financially flexible. They can increase leverage when in a good state and reduce leverage when in bad state. This study aims to fill the gap by investigating the interactions among leverage, growth and investment, and explores how relying on short-term debt helps Chinese firms make efficient investment decisions.

The unique features of Chinese listed firms provide an interesting setting to investigate how the financing decisions of Chinese firms affect their investment decisions. First, Chinese listed firms receive a significant proportion of their debt from financial institutions, rather than from financial markets, and rely more on short-term debt (Cai et al. 2008; Jiang et al. 2017). Second, the Chinese regulatory systems, such as for the corporate governance structure and banking system, are based on modern socialization characteristics, which are different from western economies (Chen et al. 2006; Fan et al. 2007; Gul 1999; Lam and Du 2004). Finally, almost all Chinese listed firms are either directly owned or controlled by state authorities (Lin and Su 2008). The current study makes an interesting contribution to the literature by investigating agency theory in the Chinese context, which was developed for western economies. Specifically, we examine to what extent short-term debt policy helps Chinese firms to make efficient financing decisions and exploit valuable growth opportunities.

This study offers several contributions to the literature. First, we investigate whether leverage plays a disciplining and monitoring role for low-growth firms to reduce the overinvestment problem. Our results suggest that leverage is negatively related to 
subsequent investment and reduces the positive effect of growth on subsequent investment for low-growth firms. Therefore, the findings suggest that leverage reduces the overinvestment problem in low-growth firms. Second, this study investigates whether relying on short-term debt helps Chinese firms to make efficient investment decisions. The findings reveal growth is positively related with subsequent investment and that leverage enhances the positive impact of growth on subsequent investment. Therefore, our findings suggest that relying on short-term debt in fact helps Chinese firms make efficient investment decisions. These results are consistent across different types of firm ownership that is, state-owned enterprises (SOEs) and non-state-owned enterprises (NSOEs), and by considering alternative proxies for investment.

The rest of the study is organized as follows. Section two includes a literature review and develops the study's hypotheses. Section three discusses the research methodology. Section four reports and discusses the results and section five provides the conclusion.

\section{Literature review and development of hypotheses}

Leverage can play a monitoring and advisory role and help firms reduce their exposure to overinvestment problem. Jensen (1986) and Stulz (1990) both suggest that leverage restricts firms from investing in opportunities with low returns or negative NPVs and, therefore, in the absence of valuable growth opportunities, leverage can negatively affect investment.

The empirical literature provides evidence in support of the nexus between leverage and investment. For instance, Hoshi et al. (1991), Fazzari et al. (1987), Gertler and Gilchrist (1994) and Lamont (1997) all report the positive relationship between a company's investment and its internal cash flow. Scandizzo's (2004) study confirms this positive and significant relationship between corporate investment and cash flow. However, Denis and Denis (1993) suggest that increases in leverage lead to significant declines in corporate investment. Additionally, using the sample period from 1970 to 1989, and by controlling for cash flow, growth (Tobin's Q) and sales, Lang et al. (1996) argue that the evidence in fact shows that the link between leverage and corporate investment is negative. Ahn et al. (2006) also conclude that the link between leverage and investment-their study in particular considers diversified US listed firms-is negative.

Because Chinese listed firms are highly leveraged (Rehman et al. 2017), managers are compelled to pay back the principal as well as interest to creditors, which restricts them from investing in low-return opportunities. Therefore, in the absence of valuable growth opportunities, we expect that leverage affects investment negatively in Chinese listed firms, and from this assessment we propose the following hypothesis:

\section{H1. Leverage is negatively associated with subsequent investment.}

Making efficient financing decisions and reducing underinvestment can sufficiently help firms issue cost-effective debt to exercise valuable investment opportunities. Myers (1977) suggests that using short-term debt that expires before the implementation of new investment projects helps firms reduce stockholder-creditor conflict and exploit investment opportunities. Many studies provide empirical support for the argument that growth opportunities positively affect investment (Aivazian et al. 2005a; Dang 2011). 
We expect that using short-term debt helps Chinese firms sufficiently reduce underinvestment, and that a sufficient reduction in underinvestment leads Chinese firms to issue more debt to finance valuable growth opportunities and thus to exploit valuable growth opportunities. Therefore, we expect that growth opportunities positively affect subsequent investment and hence, we propose the following hypothesis:

\section{H2. Growth is positively associated with subsequent investment.}

Better financing decisions can lead a firm to an optimal level of leverage, and taking on cost-effective debt can help firms exploit valuable growth opportunities. Myers (1977) also argues that firms using low leverage or adopting short-term debt policy are expected to exploit more investment opportunities. Coad and Srhoj (2019) more recently suggest that firms with higher levels of short-term debt liability also have greater chances of exploiting valuable growth opportunities. In addition, Lemmon and Zender (2019) demonstrate that debt choice ex ante affects the ex post moral hazards.

Dang's (2011) study reports an insignificant effect of leverage on the association between growth and investment for listed firms in the UK. With these findings in mind, we expect that, by relying on short-term debt, Chinese firms can remain financially flexible and therefore more readily be able to exploit valuable growth opportunities. Since leverage reportedly enhances the positive impact of growth opportunities on subsequent investment, we propose the following hypothesis:

\section{H3. Leverage magnifies the positive impact of growth on subsequent investment.}

Jensen (1986) and Stulz (1990) both argue that, due to conflicts of interest between shareholders and managers, company managers may decide to invest available free cash flow in projects with low returns or negative NPVs; in these cases, leverage can play a disciplining and monitoring role to reduce the problem of overinvestment. In fact, leverage appears to play a monitoring and advisory role and can restrict the firms' managers from investing in projects with low returns or negative NPVs. Therefore, leverage reduces the positive impact of growth on leverage for low-growth firms. Myers (1977) suggests that short-term debt can help firms make efficient financing decisions, which can ultimately help high-growth firms to make the best use of leverage and exploit valuable growth opportunities. Therefore, leverage is expected to enhance the positive impact of growth opportunities on investment for high-growth firms. Hence, we propose the following hypothesis:

H4. Leverage magnifies the positive impact of growth on subsequent investment for high-growth firms and reduces the impact of growth on subsequent investment for lowgrowth firms.

\section{Research methodology}

\section{Sample and data}

The sample of the study includes nonfinancial firms listed on the Shenzhen and Shanghai Stock Exchanges over the period from 2007 to 2017. The adoption of new 
accounting standards in 2005 and the initiation of non-tradable shares reform in 2006 are the main reasons we restrict our sample to this ten-year period. Data are extracted from the CSMAR database. In the data filtration process, we excluded B-share listed firms, missing values and quarterly and monthly data. We only consider annual observations from A-share nonfinancial listed firms for the current study. After filtration, the final dataset comprises 2774 firms yielding 12,049 observations.

Methodology

We use DIFF GMM and SYS GMM at the second stage in the study to overcome biases. The GMM dynamic model takes the first difference of all the variables of a dynamic equation and, being robust to heteroscedasticity and cross-correlation, it overcomes all non-linear restrictions (Arellano and Bond 1991; Blundell and Bond 1998). GMM has been used in many previous studies (Brown and Petersen 2009; Guariglia 2008; Guariglia et al. 2011). The following are the econometric equations we use for the purposes of estimation:

Investment equations

$$
\begin{aligned}
& I N V S T_{i, t}=\alpha_{0}+\delta_{i n v s t} I N V S T_{i, t-1}+\alpha_{1} L E V_{i, t-1}+\alpha_{2} G_{T H} H_{i, t-1}+\alpha_{3} G T H_{i, t-1} \times L E V_{i, t-1}+x i, t^{I N V S T} \beta^{I N V S T}+u_{i, t} \\
& I N V S T_{i, t}=\alpha_{0}+\delta_{i n v s t} I N V S T_{i, t-1}+\alpha_{1} L E V_{i, t-1}+\alpha_{2} G T H_{i, t-1}+{ }_{\alpha 3} H G T H_{i, t-1} \times L E V_{i, t-1}+x i, t^{I N V S T} \beta^{I N V S T}+u_{i, t} \\
& I N V S T_{i, t}=\alpha_{0}+\delta_{i n v s t} I N V S T_{i, t-1}+\alpha_{1} L E V_{i, t-1}+\alpha_{2} G_{T H} H_{i, t-1}+{ }_{\alpha 3} L G T H_{i, t-1} \times L E V_{i, t-1}+x i, t^{I N V S T} \beta^{I N V S T}+u_{i, t}
\end{aligned}
$$

$I N V S T_{i, t}$ represents the investment, INVST $T_{t-1}$ represents the lagged value of investment, $L E V_{t-1}$ represents the lagged value of leverage, $G T H_{t-1}$ represents lagged value of growth, $G T H_{t-1} \times L E V_{t-1}$ represents the lagged value of the interaction term of growth and leverage, $H G T H_{t-1} \times L E V_{t-1}$ represents the lagged value of the interaction term of the high-growth dummy and leverage. We calculate the dummy variable by assigning a value of one if growth is higher than median value, and zero otherwise. $L G T H_{t-1} \times$ $L E V_{t-1}$ refers to the interaction term of the lagged value of the low-growth dummy and leverage, where we calculate dummy variables by assigning a value of one if growth is less than median value, and zero otherwise. $x i, t^{I N V S T}$ represents the control variables and $u_{i, t}$ represents the error term. A complete description of the variables is given in Table 1.

\section{Measurement of variables}

Investment can be defined by the ratio of capital expenditure to total assets a firm makes in 1 year. Following Firth et al. (2012), we measure investment as the change in fixed assets from the beginning of the year to the end of a year plus depreciation, scaled by the value at the beginning of the year. To check robustness, we use an alternative proxy for investment following previous studies (Duchin et al. 2010; Yang et al. 2017). We measure the alternative proxy of investment as the change in fixed assets from the beginning of the year to the end of the year scaled by total assets. Following previous studies (Coles et al. 2006; Su 2010), we use Tobin's Q as a proxy for growth (GTH) and we measure it as market value divided by the book value of assets. 
Table 1 Description of variables

\begin{tabular}{|c|c|c|}
\hline Symbol & Variable & Description \\
\hline INVST & Investment & $\begin{array}{l}\text { Investment; Change in fixed assets from the beginning of the year } \\
\text { to the end of a year plus depreciation, scaled by the value at the } \\
\text { beginning of the year. }\end{array}$ \\
\hline INVST2 & Investment2 & Change in fixed assets/ total assets \\
\hline LEV & Leverage & Total liabilities / total assets \\
\hline GTH & Tobinq & Market value/ Book value of assets \\
\hline$R O A$ & Return on Assets & EBIT/total assets \\
\hline TG & Tangibility & Fixed assets / total assets \\
\hline CFLOW & Cash Flow & Operating cash flow / total assets \\
\hline CASH & Cash & Cash and Equivalents / total assets \\
\hline BSIZE & Board Size & Total number of members of the board \\
\hline CEODUA & Dual Leadership & $\begin{array}{l}1 \text { if the chairman of the board is holding both positions i.e., chairman } \\
\text { of the board and CEO otherwise } 0\end{array}$ \\
\hline INDBOARD & Independent Directors & Ratio of independent board members to total members of the board \\
\hline SDEBTRATIO & Short-term debt ratio & $\begin{array}{l}\text { The ratio of total short-term debt to total debt. We calculate total debt } \\
\text { by adding short-term debt and long-term debt. Short term debt refers } \\
\text { to debt having maturity period less than } 1 \text { year, and long-term debt } \\
\text { refers to debt having maturity period of more than } 1 \text { year. }\end{array}$ \\
\hline
\end{tabular}

Note. This table reports variables definitions

\section{Control variables}

We control for profitability and, following Yu and Ashton (2015), we measure it as EBIT over total assets. We control for asset tangibility and, following previous studies. We control for tangibility of assets and, following Danso and Adomako (2014), we measure it as fixed assets over total assets. We use cash flow to control for a firm's free cash flows (Cleary 1999; Fazzari et al. 1987). There is also documented evidence for cash flow sensitivity to corporate investment (Chow and Fung 1998; Héricourt and Poncet 2009; Poncet et al. 2010). Following Fan et al. (2017), we measure free cash flows as operating cash flow over total assets. Following Yang et al. (2017), we control for cash $(C A S H)$ and we measure it by dividing cash and cash equivalents over total assets.

We also control for variables of corporate governance, including board size, board independence and dual leadership. We calculate board size as the total number of members of the corporate board, dual leadership by using a dummy variable, and we assign a value of one if the CEO is also the board chair, otherwise we assign it as zero. We measure board independence by the ratio of independent directors to total number of directors serving on the board.

\section{Results and discussions}

\section{Results}

\section{Descriptive statistics}

Table 2 reports the descriptive statistics. The mean value of the investment (INVST) is 0.18 , which suggests that the investment ratio to total fixed assets is $18 \%$ for Chinese listed firms. The mean value of the alternative proxy of investment (INVST2) is 0.02, which suggests that the investment ratio to total assets is $2 \%$. The mean value of 
Table 2 Descriptive statistics

\begin{tabular}{llllll}
\hline Variable & Obs & Mean & Std.Dev. & Min & Max \\
\hline INVST & 12,049 & 0.187 & 0.505 & -0.431 & 2.702 \\
INVST2 & 12,049 & 0.02 & 0.056 & -0.088 & 0.228 \\
LEV & 12,049 & 0.517 & 0.187 & 0.123 & 0.902 \\
GTH & 12,049 & 1.76 & 1.535 & 0.265 & 9.735 \\
ROA & 12,049 & 0.042 & 0.044 & -0.111 & 0.152 \\
TG & 12,049 & 0.258 & 0.182 & 0 & 0.971 \\
CFLOW & 12,049 & 0.04 & 0.069 & -0.143 & 0.202 \\
CASH & 12,049 & 0.15 & 0.097 & 0.017 & 0.471 \\
BSIZE & 12,049 & 9.02 & 1.834 & 3 & 18 \\
CEODUA & 12,049 & 0.195 & 0.396 & 0 & 1 \\
INDBOARD & 12,049 & 0.37 & 0.055 & 0.091 & 0.8 \\
SDEBTRATIO & 12,049 & 0.69 & 0.32 & 0 & 1 \\
\hline
\end{tabular}

Note. This table reports descriptive statistics of investment equation, and to remove outliers we winsorise the observations at 1st and 98th following previous studies (Aivazian et al. 2005b; Dang 2011). Definitions of variables are given in Table 1

leverage is 0.51 , which suggests that Chinese firms' capital structure comprises $51 \%$ of leverage. The mean value of Tobin's Q $(G T H)$ is 1.76 , which suggests that the market value of Chinese firms is more than the cost of its assets. The mean value of sales growth $(S G T H)$ is 0.17 , which suggests that the sales growth rate in Chinese firms is approximately $17 \%$. The mean value of the short-term debt ratio (SDEBTRATIO) is 0.69, which suggests that short-term debt comprises $69 \%$ of total debt in Chinese firms. The mean values of return on assets (ROA), tangibility (TG), cash flow (CFLOW) and cash $(C A S H)$ are $0.042,0.25,0.04$ and 0.15 , respectively. This indicates that the return on assets is $4.2 \%$, the ratio of tangible assets to total assets is $25 \%$, the ratio of operating cash flow to total assets is $4 \%$ and the ratio of cash to total assets is $15 \%$. The mean values of board size (BSIZE), dual leadership (CEODUA), and board independence $(I N D B O A R D)$ are 9.02, 0.19 and 0.37, respectively. This suggests that Chinese firms, on average, have nine board members, feature dual leadership in $19 \%$ of firms, and the independent board ratio is $37 \%$ of total board members.

\section{Findings of pairwise correlation analysis and multicollinearity test}

Table 3 reports the results of the correlation analysis between the dependent and explanatory variables, including multicollinearity tests. All the variables have variance inflation factor (VIF) values less than 2, which suggests that there are no issues of multicollinearity present among the variables. The findings show that the lagged leverage value $\left(L E V_{t-1}\right)$, lagged return on assets value $\left(R O A_{t-1}\right)$, lagged tangibility value $\left(T G_{t-1}\right)$, lagged cash and equivalents value $\left(C A S H_{t-1}\right)$ and lagged board size value (BSI$Z E_{t-1}$ ) have a negative correlation with investment (INVST). These findings suggest that leverage, return on assets, tangibility, cash and equivalents and board size all have a negative association with investment. The negative association between leverage and investment is in line with Hypothesis 1 . The results further suggest that the lagged value of growth $\left(G T H_{t-1}\right)$, lagged value of cash flow $\left(C F L O W_{t-1}\right)$, lagged value of dual leadership $\left(\right.$ CEODUA $\left.A_{t-1}\right)$ and lagged value of board independence $\left(\right.$ INDBOARD $\left._{t-1}\right)$ all have a 
Table 3 Pairwise correlation and results of multicollinearity test

\begin{tabular}{|c|c|c|c|c|c|c|c|c|c|c|c|}
\hline Variables & (1) & $(2)$ & (3) & (4) & (5) & (6) & (7) & (8) & (9) & $(10)$ & VIF \\
\hline (1) INVST & 1.000 & & & & & & & & & & \\
\hline (2) $L E V_{t-1}$ & $-0.01^{*}$ & 1.000 & & & & & & & & & 1.36 \\
\hline (3) $G T H_{t-1}$ & $0.06^{*}$ & $-0.42^{*}$ & 1.00 & & & & & & & & 1.26 \\
\hline (4) $R O A_{t-1}$ & $-0.07^{*}$ & $-0.28^{*}$ & $0.15^{*}$ & 1.00 & & & & & & & 1.25 \\
\hline (5) $T G_{t-1}$ & $-0.17^{*}$ & $0.03^{*}$ & $-0.12^{*}$ & $-0.04^{*}$ & 1.00 & & & & & & 1.37 \\
\hline (6) $C F L O W_{t-1}$ & $0.03^{*}$ & $-0.16^{*}$ & $0.05^{*}$ & $0.34^{*}$ & $0.30^{*}$ & 1.00 & & & & & 1.34 \\
\hline (7) $\mathrm{CASH}_{t-1}$ & $-0.06^{*}$ & $-0.22^{*}$ & $0.15^{*}$ & $0.12^{*}$ & $-0.33^{*}$ & $0.10^{*}$ & 1.00 & & & & 1.24 \\
\hline (8) $B S I Z E_{t-1}$ & $-0.02^{*}$ & $0.11^{*}$ & $-0.16^{*}$ & $0.03^{*}$ & $0.16^{*}$ & $0.07^{*}$ & $-0.02^{*}$ & 1.00 & & & 1.23 \\
\hline (9) CEODUA & $0.03^{*}$ & $-0.11^{*}$ & $0.13^{*}$ & 0.02 & $-0.06^{*}$ & $-0.02^{*}$ & $0.04^{*}$ & $-0.15^{*}$ & 1.00 & & 1.04 \\
\hline (10)INDBOARD ${ }_{t-1}$ & 0.01 & 0.03 & $0.03^{*}$ & $-0.04^{*}$ & $-0.07^{*}$ & $-0.04^{*}$ & 0.01 & $-0.35^{*}$ & $0.07^{*}$ & 1.00 & 1.15 \\
\hline
\end{tabular}

positive correlation with investment (INVST). These findings reveal that growth, cash flow, dual leadership and board independence are positively associated with investment. This positive association of growth and investment is in line with Hypothesis 2.

\section{Findings of the investment equation}

Table 4 reports the findings of the basic investment equation. We report the results of DIFF GMM in columns (1) and (2) and the results of SYS GMM in columns (3) and (4). We excluded growth from columns (2) and (4) to avoid any possible interaction between growth and the interaction terms of growth and leverage. To test the validity of the dynamic models, we use the Sargan test and Arellano-Bond test to check the over-identification of instruments and serial correlation in the residual values. Sargan test's $p$-value and $A R(2)$ are above 10\%, which supports the validity of the model (Arellano and Bond 1991; Blundell and Bond 1998). The lagged value of investment has significant coefficients in all columns, which supports our decision to choose a dynamic model for the analysis.

The coefficients of lagged value of leverage $\left(L E V_{t-1}\right)$ in columns (1) to (4) are -0.214 , $-0.701,-0.235$ and -0.727 . The coefficients of the lagged value of leverage $\left(L E V_{t-1}\right)$ in columns (1) and (3) are negative and significant at the $10 \%$ level, and in columns (2) and (4), the coefficients of the lagged value of leverage $\left(L E V_{t-1}\right)$ are negative and significant at the $1 \%$ level. The results reveal that leverage has a negative association with investment, which is in line with Hypothesis 1 . The coefficients of the lagged value of growth $\left(G T H_{t-1}\right)$ in columns (1) and (3) are 0.103 and 0.103 , respectively, which are positive and significant at the $1 \%$ level. These findings suggest that growth has a positive association with investment, which is consistent with Hypothesis 2.

The coefficients of the lagged value of the interaction terms for leverage and growth $\left(L E V_{t-1}{ }^{*} G T H_{t-1}\right)$ in columns (2) and (4) are 0.204 and 0.208 , respectively, which are positive and significant at the $1 \%$ level. This result demonstrates that leverage enhances the positive effect of growth on investment, which is in line with Hypothesis 3.

\section{High-growth and low-growth firms}

Table 5 reports the findings of the investment equation for high-growth and lowgrowth firms. Results for the baseline of the investment equation are reported in 
Table 4 Findings of the Investment equation

\begin{tabular}{|c|c|c|c|c|}
\hline \multirow[b]{3}{*}{ Variables } & \multicolumn{4}{|c|}{ Dependent Variable: Investment } \\
\hline & $(1)$ & (2) & (3) & (4) \\
\hline & \multicolumn{2}{|l|}{ DIFF GMM } & \multicolumn{2}{|l|}{ SYS GMM } \\
\hline \multirow[t]{2}{*}{$\mathrm{INVST}_{t-1}$} & $0.0200^{* *}$ & $0.0206^{* *}$ & $0.0164^{* *}$ & $0.0164^{* *}$ \\
\hline & $(0.0151)$ & $(0.0153)$ & $(0.0144)$ & $(0.0146)$ \\
\hline \multirow[t]{2}{*}{$L E V_{t-1}$} & $-0.214^{*}$ & $-0.701^{* * *}$ & $-0.235^{*}$ & $-0.727^{* * *}$ \\
\hline & $(0.142)$ & $(0.146)$ & $(0.139)$ & $(0.142)$ \\
\hline \multirow[t]{2}{*}{$G T H_{t-1}$} & $0.103^{* * *}$ & & $0.103^{* * *}$ & \\
\hline & $(0.0126)$ & & $(0.0125)$ & \\
\hline \multirow[t]{2}{*}{$L E V_{t-1}^{*} G T H_{t-1}$} & & $0.204^{* * *}$ & & $0.208^{* * *}$ \\
\hline & & $(0.0271)$ & & $(0.0268)$ \\
\hline \multirow[t]{2}{*}{$R O A_{t-1}$} & $-0.957^{* * *}$ & $-0.968^{* * *}$ & $-0.957^{* * *}$ & $-0.973^{* * *}$ \\
\hline & $(0.214)$ & $(0.213)$ & $(0.211)$ & $(0.209)$ \\
\hline \multirow[t]{2}{*}{$T G_{t-1}$} & $-4.207^{* * *}$ & $-4.232^{* * *}$ & $-4.158^{* * *}$ & $-4.182^{* * *}$ \\
\hline & $(0.165)$ & $(0.166)$ & $(0.162)$ & $(0.161)$ \\
\hline \multirow[t]{2}{*}{ CFLOW $_{t-1}$} & $0.373^{* * *}$ & $0.386^{* * *}$ & $0.385^{* * *}$ & $0.397^{* * *}$ \\
\hline & $(0.122)$ & $(0.120)$ & $(0.119)$ & $(0.117)$ \\
\hline \multirow[t]{2}{*}{$\mathrm{CASH}_{t-1}$} & $-0.803^{* * *}$ & $-0.806^{* * *}$ & $-0.804^{* * *}$ & $-0.805^{* * *}$ \\
\hline & $(0.163)$ & $(0.164)$ & $(0.161)$ & $(0.162)$ \\
\hline \multirow[t]{2}{*}{$B S I Z E_{t-1}$} & -0.00476 & -0.00598 & -0.00700 & -0.00806 \\
\hline & $(0.0107)$ & $(0.0108)$ & $(0.0105)$ & $(0.0105)$ \\
\hline \multirow[t]{2}{*}{ CEODUA $_{t-1}$} & 0.0185 & 0.0172 & 0.0172 & 0.0156 \\
\hline & $(0.0324)$ & $(0.0328)$ & $(0.0318)$ & $(0.0322)$ \\
\hline \multirow[t]{2}{*}{$I_{N D B O A R D_{t-1}}$} & -0.0393 & -0.0717 & -0.0604 & -0.0900 \\
\hline & $(0.209)$ & $(0.207)$ & $(0.206)$ & $(0.204)$ \\
\hline \multirow[t]{2}{*}{ Constant } & $1.478^{* * *}$ & $1.773^{* * *}$ & $1.508^{* * *}$ & $1.798^{* * *}$ \\
\hline & $(0.182)$ & $(0.182)$ & $(0.177)$ & $(0.177)$ \\
\hline Year & Yes & Yes & Yes & Yes \\
\hline Observations & 7684 & 7684 & 7684 & 7684 \\
\hline$A R(1)$ & $-12.79^{* * *}$ & $-12.83^{* * *}$ & $-12.82^{* * *}$ & $-12.86^{* * *}$ \\
\hline$A R(2)$ & 0.51 & 0.55 & 0.43 & 0.45 \\
\hline Sargan ( $p$-value) & 0.43 & 0.43 & 0.61 & 0.63 \\
\hline
\end{tabular}

Note. This table reports findings of investment equation. Arrellano-Bond tests are represented by AR (1) \& AR (2) for serial correlation in residuals. Sargan ( $p$-value) refers to the $p$-value of Sargan test to check the over-identification of instruments. Values of standard errors are given in parenthesis. Definitions of variables are given in Table 1. **** $^{* *}$, and * shows the level of significance at $1 \%, 5 \%$, and $10 \%$

columns (1) and (4). The results for DIFF GMM and SYS GMM are reported in columns (2) and (5) for high-growth firms, and the results of DIFF GMM and SYS GMM for low-growth firms are reported in columns (3) and (6). To test the validity of dynamic models, we use the Sargan test and Arellano-Bond test to check the overidentification of instruments and serial correlation in the residuals. The Sargan test's $p$ value and $A R(2)$ are above $10 \%$, which supports the validity of the model. Consistent with previous results, the lagged value of investment has significant coefficients in all columns and, hence, supports our decision to choose a dynamic model for the analysis.

The coefficients of the lagged value of leverage $\left(L E V_{t-1}\right)$ found in columns (2) to (6) are $-0.296,-0.286,-0.235,-0.318$ and -0.309 , respectively. The coefficients of the 
Table 5 Findings of Investment equation in high growth and low growth firms

\begin{tabular}{|c|c|c|c|c|c|c|}
\hline \multirow[b]{4}{*}{ Variables } & \multicolumn{6}{|c|}{ Dependent Variable: Investment } \\
\hline & \multirow[t]{2}{*}{$\overline{(1)}$} & (2) & (3) & (4) & (5) & (6) \\
\hline & & High Growth & Low Growth & & High Growth & Low Growth \\
\hline & \multicolumn{3}{|l|}{ DIFF GMM } & \multicolumn{3}{|l|}{ SYS GMM } \\
\hline \multirow[t]{2}{*}{$\overline{I N V S T_{t-1}}$} & $0.0200^{* *}$ & $0.0235^{* * *}$ & $0.0233^{* * *}$ & $0.0164^{* *}$ & $0.0199^{* *}$ & $0.0196^{* *}$ \\
\hline & $(0.0151)$ & $(0.0149)$ & $(0.0150)$ & $(0.0144)$ & $(0.0143)$ & $(0.0144)$ \\
\hline \multirow[t]{2}{*}{$L E V_{t-1}$} & -0.214 & $-0.296^{* *}$ & $-0.286^{* *}$ & $-0.235^{*}$ & $-0.318^{* *}$ & $-0.309^{* *}$ \\
\hline & $(0.142)$ & $(0.141)$ & $(0.143)$ & $(0.139)$ & $(0.138)$ & $(0.140)$ \\
\hline \multirow[t]{2}{*}{$G T H_{t-1}$} & $0.103^{* * *}$ & & & $0.103^{* * *}$ & & \\
\hline & $(0.0126)$ & & & $(0.0125)$ & & \\
\hline \multirow[t]{2}{*}{$\operatorname{LEV}_{t-1 *} H_{G T H}$} & & $0.291^{* * *}$ & & & $0.301^{* * *}$ & \\
\hline & & $(0.0408)$ & & & $(0.0402)$ & \\
\hline \multirow[t]{2}{*}{$L E V_{t-1^{*}} L G T H_{t-1}$} & & & $-0.293^{* * *}$ & & & $-0.299 * * *$ \\
\hline & & & $(0.0395)$ & & & $(0.0390)$ \\
\hline \multirow[t]{2}{*}{$R O A_{t-1}$} & $-0.0911^{* * *}$ & $-0.0904^{* * *}$ & $-0.0924^{* * *}$ & $-0.0953^{* * *}$ & $-0.0938^{* * *}$ & $-0.0959^{* * *}$ \\
\hline & $(0.0283)$ & $(0.0291)$ & $(0.0290)$ & $(0.0278)$ & $(0.0286)$ & $(0.0286)$ \\
\hline \multirow[t]{2}{*}{$T G_{t-1}$} & $-4.207^{* * *}$ & $-4.144^{* * *}$ & $-4.154^{* * *}$ & $-4.158^{* * *}$ & $-4.089^{* * *}$ & $-4.101^{* * *}$ \\
\hline & $(0.165)$ & $(0.170)$ & $(0.169)$ & $(0.162)$ & $(0.166)$ & $(0.165)$ \\
\hline \multirow[t]{2}{*}{ CFLOW $_{t-1}$} & $0.373^{* * *}$ & $0.478^{* * *}$ & $0.460^{* * *}$ & $0.385^{* * *}$ & $0.489^{* * *}$ & $0.472^{* * *}$ \\
\hline & $(0.122)$ & $(0.122)$ & $(0.122)$ & $(0.119)$ & $(0.120)$ & $(0.120)$ \\
\hline \multirow[t]{2}{*}{$\mathrm{CASH}_{t-1}$} & $-0.803^{* * *}$ & $-0.840^{* * *}$ & $-0.858^{* * *}$ & $-0.804^{* * *}$ & $-0.844^{* * *}$ & $-0.864^{* * *}$ \\
\hline & $(0.163)$ & $(0.165)$ & $(0.165)$ & $(0.161)$ & $(0.163)$ & $(0.163)$ \\
\hline \multirow[t]{2}{*}{$B S I Z E_{t-1}$} & -0.00476 & -0.00206 & -0.00222 & -0.00700 & -0.00438 & -0.00441 \\
\hline & $(0.0107)$ & $(0.0105)$ & $(0.0105)$ & $(0.0105)$ & $(0.0103)$ & $(0.0103)$ \\
\hline \multirow[t]{2}{*}{ CEODUA $A_{t-1}$} & 0.0185 & 0.00369 & 0.00536 & 0.0172 & 0.00189 & 0.00358 \\
\hline & $(0.0324)$ & $(0.0330)$ & $(0.0330)$ & $(0.0318)$ & $(0.0324)$ & $(0.0324)$ \\
\hline \multirow[t]{2}{*}{$I_{N D B O A R D_{t-1}}$} & -0.0393 & -0.0500 & -0.0231 & -0.0604 & -0.0728 & -0.0445 \\
\hline & $(0.209)$ & $(0.208)$ & $(0.208)$ & $(0.206)$ & $(0.205)$ & $(0.206)$ \\
\hline \multirow[t]{2}{*}{ Constant } & $1.478^{* * *}$ & $1.582^{* * *}$ & $1.736^{* * *}$ & $1.508^{* * *}$ & $1.610^{* * *}$ & $1.767^{* * *}$ \\
\hline & $(0.182)$ & $(0.179)$ & $(0.180)$ & $(0.177)$ & $(0.174)$ & $(0.175)$ \\
\hline Year & Yes & Yes & Yes & Yes & Yes & Yes \\
\hline Observations & 7684 & 7684 & 7684 & 7684 & 7684 & 7684 \\
\hline$A R(1)$ & $-12.79^{* * *}$ & $-12.97^{* * *}$ & $-13.00^{* * *}$ & $-12.82^{* * *}$ & $-13.04^{* * *}$ & $-13.06^{* * *}$ \\
\hline$A R(2)$ & 0.51 & 0.52 & 0.47 & 0.43 & 0.43 & 0.38 \\
\hline Sargan ( $p$-value) & 0.43 & 0.13 & 0.27 & 0.61 & 0.20 & 0.41 \\
\hline
\end{tabular}

Note. This table reports findings of investment equation for high growth \& low growth firms. Arrellano-Bond tests are represented by AR (1) \& AR (2) for serial correlation in residuals. Sargan ( $p$-value) refers to the $p$-value of Sargan test to check the over-identification of instruments. Values of standard errors are given in parenthesis. Definitions of variables are given in Table 1. ${ }^{* * *},{ }^{* *}$, and ${ }^{*}$ shows the level of significance at $1 \%, 5 \%$, and $10 \%$

lagged value of leverage in columns (2), (3), (5) and (6) are negative and significant at the $5 \%$ level, and in column (4) is negative and significant at the $10 \%$ level. The coefficients of the lagged value of growth in columns (1) and (4) are 0.103 and 0.103 , respectively, which are positive and significant at the $1 \%$ level. The coefficients of the lagged value of growth and leverage are in line with our main results.

The coefficients of the lagged value of the interaction terms leverage and highgrowth dummy (LEV $\left.t-1{ }^{*} H G T H_{t-1}\right)$ in columns (2) and (5) are 0.291 and 0.301, 
respectively, which are positive and significant at the $1 \%$ level. These findings support the argument that leverage helps high-growth firms execute valuable growth opportunities. The coefficients of the lagged value of interaction terms of leverage and the lowgrowth dummy (LEV $t-1$ * $\left.L G T H_{t-1}\right)$ in columns (3) and (6) are -0.293 and-0.299, respectively, which are negative and significant at the $1 \%$ level. The findings support the argument that leverage plays a moderating role and reduces the impact of growth on investment for low-growth firms, conditions which are consistent with Hypothesis 4.

\section{Additional analysis of the investment equation in SOEs and NSOEs}

Financial constraints do not allow firms to make a change in the debt structure (Dang 2011). Furthermore, Cai et al. (2008) argue that the government financially supports some large Chinese firms. However, Howell (2020) document evidence that NSOEs perform better in innovation as compared with their state-owned counterparts. We expect that, because SOEs in China are financially supported by the government, they generally face fewer financial constraints than NSOEs, therefore can be more stable. For instance, Wen et al. (2019) document evidence that relationship between the intentions of investors in retail and stock price cash risk is less prominent for SOEs. To investigate the behavior of firms with different nature of ownership like SOEs and NSOEs, we conduct a separate analysis across different types of firm ownership.

Table 6 reports the findings of the additional analysis of the investment equation separately for SOEs and NSOEs. We used DIFF GMM for the analysis, and report results for SOEs in columns (1) and (2) and for NSOEs in columns (3) and (4). To test the validity of the dynamic models, we use the Sargan test and Arellano-Bond test to check the over-identification of instruments and serial correlation in the residuals. The Sargan test's $p$-value and $A R(2)$ are above $10 \%$, which supports the validity of the model. Consistent with prior results, the coefficients for the lagged value of investment are significant and positive across all columns.

The coefficients of the lagged value of leverage $\left(L E V_{t-1}\right)$, which can be found in columns (1) to (4), are $-0.150,-0.504,-0.335$ and -0.858 . In columns (1) and (3), the coefficients of $L E V_{t-1}$ are significant and negative at the $10 \%$ level, and the coefficients of $L E V_{t-1}$ in columns (2) and (4) are negative and significant at the $1 \%$ level. The coefficients of the lagged value of growth $\left(G T H_{t-1}\right)$ in columns (1) and (3) are 0.159 and 0.0928; both coefficients are positive and significant at the $1 \%$ level. Moreover, the coefficients for the lagged value of interaction terms leverage and growth $\left(L E V_{t-1}{ }^{*} G T H_{t-1}\right)$ in columns (2) and (4) are 0.322 and 0.200 ; both coefficients are positive and significant at the $1 \%$ level. Overall, the findings across different types of firm ownership are consistent with our main results.

Table 7 reports the findings of the investment equation separately for high-growth and low-growth SOEs and NSOEs. Columns (1) and (4) report the findings of the baseline investment equation for SOEs and NSOEs. We report the results of DIFF GMM in columns (2) and (5) for high-growth SOEs and NSOEs, and report results of DIFF GMM in columns (3) and (6) for low-growth SOEs and NSOEs. To test the validity of the dynamic models, we use a Sargan test and Arellano-Bond test to check the overidentification of the instruments and serial correlation in the residuals. The Sargan 
Table 6 Findings of Investment equation in SOEs and NSOES

\begin{tabular}{|c|c|c|c|c|}
\hline \multirow[b]{4}{*}{ Variables } & \multicolumn{4}{|c|}{ Dependent Variable: Investment } \\
\hline & $\overline{(1)}$ & (2) & (3) & (4) \\
\hline & \multicolumn{2}{|l|}{ SOES } & \multicolumn{2}{|l|}{ NSOES } \\
\hline & DIFF GMM & & & \\
\hline \multirow[t]{2}{*}{${ }_{I N V S T_{t-1}}$} & $0.0230^{* *}$ & $0.0226^{* *}$ & $0.0224^{* *}$ & $0.0199^{* *}$ \\
\hline & $(0.0175)$ & $(0.0178)$ & $(0.0204)$ & $(0.0205)$ \\
\hline \multirow[t]{2}{*}{$L E V_{t-1}$} & $-0.150^{*}$ & $-0.504^{* * *}$ & $-0.335^{*}$ & $-0.858^{* * *}$ \\
\hline & $(0.193)$ & $(0.186)$ & $(0.177)$ & $(0.191)$ \\
\hline \multirow[t]{2}{*}{$\mathrm{GTH}_{t-1}$} & $0.159 * * *$ & & $0.0928^{* * *}$ & \\
\hline & $(0.0194)$ & & $(0.0169)$ & \\
\hline \multirow[t]{2}{*}{ LEV $_{t-1^{*}}$ GTH $_{t-1}$} & & $0.322^{* * *}$ & & $0.200^{* * *}$ \\
\hline & & $(0.0362)$ & & $(0.0332)$ \\
\hline \multirow[t]{2}{*}{$R O A_{t-1}$} & $-0.483^{* *}$ & $-0.519^{* *}$ & $-1.293^{* * *}$ & $-1.266^{* * *}$ \\
\hline & $(0.244)$ & $(0.234)$ & $(0.324)$ & $(0.328)$ \\
\hline \multirow[t]{2}{*}{$T G_{t-1}$} & $-3.675^{* * *}$ & $-3.649^{* * *}$ & $-4.766^{* * *}$ & $-4.760^{* * *}$ \\
\hline & $(0.184)$ & $(0.180)$ & $(0.280)$ & $(0.276)$ \\
\hline \multirow[t]{2}{*}{ CFLOW $_{t-1}$} & $0.303^{*}$ & $0.315^{* *}$ & $0.423^{* * *}$ & $0.424^{* * *}$ \\
\hline & $(0.162)$ & $(0.160)$ & $(0.163)$ & $(0.160)$ \\
\hline \multirow[t]{2}{*}{$\mathrm{CASH}_{t-1}$} & $-0.746^{* * *}$ & $-0.707^{* * *}$ & $-0.921^{* * *}$ & $-0.923^{* * *}$ \\
\hline & $(0.239)$ & $(0.238)$ & $(0.199)$ & $(0.198)$ \\
\hline \multirow[t]{2}{*}{$B S I Z E_{t-1}$} & 0.00773 & 0.00675 & -0.0161 & -0.0159 \\
\hline & $(0.0113)$ & $(0.0112)$ & $(0.0184)$ & $(0.0188)$ \\
\hline \multirow[t]{2}{*}{ CEODUA $_{t-1}$} & 0.0358 & 0.0226 & -0.0261 & -0.0204 \\
\hline & $(0.0339)$ & $(0.0338)$ & $(0.0470)$ & $(0.0478)$ \\
\hline \multirow[t]{2}{*}{ INDBOARD $_{t-1}$} & -0.408 & $-0.445^{*}$ & 0.203 & 0.203 \\
\hline & $(0.268)$ & $(0.264)$ & $(0.292)$ & $(0.292)$ \\
\hline \multirow[t]{2}{*}{ Constant } & $1.063^{* * *}$ & $1.439 * * *$ & $1.630^{* * *}$ & $1.887^{* * *}$ \\
\hline & $(0.226)$ & $(0.217)$ & $(0.268)$ & $(0.268)$ \\
\hline Year & Yes & Yes & Yes & Yes \\
\hline Observations & 4239 & 4239 & 3445 & 3445 \\
\hline$A R(1)$ & $-9.18^{* * *}$ & $-9.15^{* * *}$ & $-8.73^{* * *}$ & $-8.72^{* * *}$ \\
\hline$A R(2)$ & 1.35 & 1.45 & -0.20 & -0.21 \\
\hline Sargan ( $p$-value) & 0.23 & 0.30 & 0.35 & 0.51 \\
\hline
\end{tabular}

Note. This table reports findings of investment equation in SOEs and NSOEs. Arrellano-Bond tests are represented by AR (1) \& AR (2) for serial correlation in residuals. Sargan ( $p$-value) refers to the $p$-value of Sargan test to check the overidentification of instruments. Values of standard errors are given in parenthesis. Definitions of variables are given in Table $1 . *^{* *}, * *$ and ${ }^{*}$ shows the level of significance at $1 \%, 5 \%$, and $10 \%$

test's $p$-value and $A R(2)$ are above $10 \%$, which supports the validity of the model. Consistent with previous results, the lagged value of investment has significant coefficients in all columns and, hence, supports our decision to choose a dynamic model for the analysis.

The coefficients of the lagged value of leverage $\left(L E V_{t-1}\right)$, found in columns (4) to (6), are $-0.335,-0.385$, and -0.381 , respectively. In column (4), the coefficient of $L E V_{t-1}$ is negative and significant at the $10 \%$ level and, in columns (5) and (6), the coefficients of $L E V_{t-1}$ are negatively significant at the $5 \%$ level. The coefficients of the lagged value of 
Table 7 Findings of Investment equation in SOEs and NSOEs for high growth and low growth firms

\begin{tabular}{|c|c|c|c|c|c|c|}
\hline \multirow[b]{5}{*}{ Variables } & \multicolumn{6}{|c|}{ Dependent Variable: Investment } \\
\hline & $(1)$ & $(2)$ & (3) & (4) & (5) & (6) \\
\hline & & High Growth & Low Growth & & High Growth & Low Growth \\
\hline & \multicolumn{3}{|l|}{ SOES } & \multicolumn{3}{|l|}{ NSOES } \\
\hline & \multicolumn{6}{|l|}{ DIFF GMM } \\
\hline \multirow[t]{2}{*}{$\overline{I N V S T_{t-1}}$} & $0.0230^{* *}$ & $0.0334^{* *}$ & $0.0290^{* *}$ & $0.0224^{* *}$ & $0.0304^{* *}$ & $0.0285^{* *}$ \\
\hline & $(0.0175)$ & $(0.0178)$ & $(0.0178)$ & $(0.0204)$ & $(0.0203)$ & $(0.0203)$ \\
\hline \multirow[t]{2}{*}{$L E V_{t-1}$} & 0.150 & -0.114 & -0.0838 & $-0.335^{*}$ & $-0.385^{* *}$ & $-0.381^{* *}$ \\
\hline & $(0.193)$ & $(0.192)$ & $(0.193)$ & $(0.177)$ & $(0.178)$ & $(0.180)$ \\
\hline \multirow[t]{2}{*}{$G T H_{t-1}$} & $0.159^{* * *}$ & & & $0.0928^{* * *}$ & & \\
\hline & $(0.0194)$ & & & $(0.0169)$ & & \\
\hline \multirow{2}{*}{ LEV $_{t-1} * H G T H_{t-1}$} & & $0.312^{* * *}$ & & & $0.231^{* * *}$ & \\
\hline & & $(0.0592)$ & & & $(0.0534)$ & \\
\hline \multirow[t]{2}{*}{$L E V_{t-1}{ }^{*} L G T H_{t-1}$} & & & $-0.253^{* * *}$ & & & $-0.251^{* * *}$ \\
\hline & & & $(0.0566)$ & & & $(0.0546)$ \\
\hline \multirow[t]{2}{*}{$R O A_{t-1}$} & $-0.483^{* *}$ & -0.290 & $-0.471^{*}$ & $-1.293^{* * *}$ & $-1.213^{* * *}$ & $-1.257^{* * *}$ \\
\hline & $(0.244)$ & $(0.269)$ & $(0.262)$ & $(0.324)$ & $(0.327)$ & $(0.326)$ \\
\hline \multirow[t]{2}{*}{$T G_{t-1}$} & $-3.675^{* * *}$ & $-3.622^{* * *}$ & $-3.620^{* * *}$ & $-4.766^{* * *}$ & $-4.657^{* * *}$ & $-4.658^{* * *}$ \\
\hline & $(0.184)$ & $(0.192)$ & $(0.188)$ & $(0.280)$ & $(0.290)$ & $(0.289)$ \\
\hline \multirow[t]{2}{*}{ CFLOW $_{t-1}$} & $0.303^{*}$ & $0.388^{* *}$ & $0.326^{*}$ & $0.423^{* * *}$ & $0.590^{* * *}$ & $0.563^{* * *}$ \\
\hline & $(0.162)$ & $(0.169)$ & $(0.167)$ & $(0.163)$ & $(0.157)$ & $(0.158)$ \\
\hline \multirow[t]{2}{*}{$\mathrm{CASH}_{t-1}$} & $-0.746^{* * *}$ & $-0.695^{* * *}$ & $-0.811^{* * *}$ & $-0.921^{* * *}$ & $-0.931^{* * *}$ & $-0.946^{* * *}$ \\
\hline & $(0.239)$ & $(0.248)$ & $(0.247)$ & $(0.199)$ & $(0.201)$ & $(0.200)$ \\
\hline \multirow[t]{2}{*}{$B S I Z E_{t-1}$} & 0.00773 & 0.00973 & $7.57 \mathrm{e}-05$ & -0.0161 & -0.0100 & -0.00951 \\
\hline & $(0.0113)$ & $(0.0113)$ & $(0.0113)$ & $(0.0184)$ & $(0.0180)$ & $(0.0179)$ \\
\hline \multirow[t]{2}{*}{$C E O D \cup A_{t-1}$} & 0.0358 & 0.0414 & 0.0281 & -0.0261 & -0.0385 & -0.0347 \\
\hline & $(0.0339)$ & $(0.0351)$ & $(0.0352)$ & $(0.0470)$ & $(0.0483)$ & $(0.0481)$ \\
\hline \multirow[t]{2}{*}{$I_{N D B O A R D}$} & -0.408 & -0.393 & $-0.453^{*}$ & 0.203 & 0.211 & 0.266 \\
\hline & $(0.268)$ & $(0.266)$ & $(0.265)$ & $(0.292)$ & $(0.292)$ & $(0.294)$ \\
\hline \multirow[t]{2}{*}{ Constant } & $1.063^{* * *}$ & $1.329^{* * *}$ & $1.667^{* * *}$ & $1.630^{* * *}$ & $1.675^{* * *}$ & $1.777^{* * *}$ \\
\hline & $(0.226)$ & $(0.220)$ & $(0.229)$ & $(0.268)$ & $(0.262)$ & $(0.259)$ \\
\hline Year & Yes & Yes & Yes & Yes & Yes & Yes \\
\hline Observations & 4239 & 4239 & 4239 & 3445 & 3445 & 3445 \\
\hline$A R(1)$ & $-9.18^{* * *}$ & $-9.42^{* * *}$ & $-9.46^{* * *}$ & $-8.73^{* * *}$ & $-8.88^{* * *}$ & $-8.89 * * *$ \\
\hline$A R(2)$ & 1.35 & 1.47 & 1.37 & -0.20 & 0.10 & -0.17 \\
\hline Sargan ( $p$-value) & 0.23 & 0.42 & 0.59 & 0.35 & 0.186 & 0.29 \\
\hline
\end{tabular}

Note. This table reports the findings of Investment equation in SOEs and NSOEs for high growth \& low growth firms. Arrellano-Bond tests are denoted by AR (1) \& AR (2) for serial correlation in residuals. Sargan ( $p$-value) refers to the $p$ value of Sargan test to check the over-identification of instruments. Values of standard errors are given in parenthesis. Definitions of variables are given in Table 1. ${ }^{* *}$, **, and * shows the level of significance at $1 \%, 5 \%$, and $10 \%$

growth in columns (1) and (4) are 0.159 and 0.0928 , respectively, which are positive and significant at the $1 \%$ level. These coefficients are all in line with our main results.

The coefficients of the lagged value of the interaction term of leverage and highgrowth dummy $\left(L E V_{t-1}{ }^{*} H G T H_{t-1}\right)$ in columns (2) and (5) are 0.312 and 0.231 , 
respectively, which are positive and significant at the $1 \%$ level. The coefficients of the lagged value of interaction term of leverage and low-growth dummy $\left(L E V_{t-1} * L G T H_{t-1}\right)$ in columns (3) and (6) are -0.253 and -0.251 , respectively, which are negative and significant at the $1 \%$ level. These findings are in line with our main results.

\section{Robust test using an alternative proxy for investment}

Table 8 reports the findings of the investment equation with an alternative proxy for investment. We report the results of DIFF GMM in columns (1) and (2) and the results of SYS GMM in columns (3) and (4). The Sargan test's $p$-value and AR (2) are above

Table 8 Findings of Investment equation with an alternative proxy of investment

\begin{tabular}{|c|c|c|c|c|}
\hline \multirow[b]{3}{*}{ Variables } & \multicolumn{4}{|c|}{ Dependent Variable: INVST2 (an alternative proxy of investment) } \\
\hline & (1) & $(2)$ & (3) & (4) \\
\hline & DIFF GMM & DIFF GMM & SYS GMM & SYS GMM \\
\hline \multirow[t]{2}{*}{ INVST2 $_{t-1}$} & $0.0596^{* * *}$ & $0.0621^{* * *}$ & $0.0631^{* * *}$ & $0.0653^{* * *}$ \\
\hline & $(0.0165)$ & $(0.0165)$ & $(0.0160)$ & $(0.0160)$ \\
\hline \multirow[t]{2}{*}{$L E V_{t-1}$} & $-0.0157^{*}$ & $-0.0673^{* * *}$ & $-0.0205^{*}$ & $-0.0718^{* * *}$ \\
\hline & $(0.0158)$ & $(0.0157)$ & $(0.0153)$ & $(0.0153)$ \\
\hline \multirow[t]{2}{*}{$\mathrm{GTH}_{t-1}$} & $0.00965^{* * *}$ & & $0.00938^{* * *}$ & \\
\hline & $(0.00137)$ & & $(0.00134)$ & \\
\hline \multirow[t]{2}{*}{ LEV $_{t-1} * G T H_{t-1}$} & & $0.0217^{* * *}$ & & $0.0217^{* * *}$ \\
\hline & & $(0.00286)$ & & $(0.00277)$ \\
\hline \multirow[t]{2}{*}{$R O A_{t-1}$} & $-0.0911^{* * *}$ & $-0.0921^{* * *}$ & $-0.0953^{* * *}$ & $-0.0968^{* * *}$ \\
\hline & $(0.0283)$ & $(0.0282)$ & $(0.0278)$ & $(0.0278)$ \\
\hline \multirow[t]{2}{*}{$T G_{t-1}$} & $-0.686^{* * *}$ & $-0.687^{* * *}$ & $-0.663^{* * *}$ & $-0.665^{* * *}$ \\
\hline & $(0.0250)$ & $(0.0248)$ & $(0.0234)$ & $(0.0232)$ \\
\hline \multirow[t]{2}{*}{ CFLOW } & $0.0570^{* * *}$ & $0.0559^{* * *}$ & $0.0546^{* * *}$ & $0.0532^{* * *}$ \\
\hline & $(0.0122)$ & $(0.0121)$ & $(0.0120)$ & $(0.0119)$ \\
\hline \multirow[t]{2}{*}{$\mathrm{CASH}_{t-1}$} & $-0.132^{* * *}$ & $-0.131^{* * *}$ & $-0.130^{* * *}$ & $-0.129^{* * *}$ \\
\hline & $(0.0181)$ & $(0.0179)$ & $(0.0176)$ & $(0.0174)$ \\
\hline \multirow[t]{2}{*}{$B S I Z E_{t-1}$} & -0.00132 & -0.00133 & -0.00166 & -0.00165 \\
\hline & $(0.00115)$ & $(0.00116)$ & $(0.00112)$ & $(0.00113)$ \\
\hline \multirow[t]{2}{*}{ CEODUA $_{t-1}$} & -0.00147 & -0.00133 & -0.000950 & -0.000681 \\
\hline & $(0.00343)$ & $(0.00343)$ & $(0.00335)$ & $(0.00335)$ \\
\hline \multirow[t]{2}{*}{ INDBOARD $_{t-1}$} & -0.00885 & -0.0138 & -0.0115 & -0.0161 \\
\hline & $(0.0267)$ & $(0.0265)$ & $(0.0264)$ & $(0.0262)$ \\
\hline \multirow[t]{2}{*}{ Constant } & $0.228^{* * *}$ & $0.257^{* * *}$ & $0.227^{* * *}$ & $0.256^{* * *}$ \\
\hline & $(0.0219)$ & $(0.0210)$ & $(0.0214)$ & $(0.0205)$ \\
\hline Year & Yes & Yes & Yes & Yes \\
\hline Observations & 5954 & 5954 & 7684 & 7684 \\
\hline$A R(1)$ & $-12.11^{* * *}$ & $-11.98^{* * *}$ & $-12.2^{* * *}$ & $-12.07^{* * *}$ \\
\hline$A R(2)$ & 0.12 & 0.18 & -0.52 & -0.46 \\
\hline Sargan (p-value) & 0.33 & 0.32 & 0.16 & 0.15 \\
\hline
\end{tabular}

Note. This table reports findings of investment equation with an alternative proxy of investment. Arrellano-Bond tests are represented by AR (1) \& AR (2) for serial correlation in residuals. Sargan ( $p$-value) refers to the $p$-value of Sargan test to check the over-identification of instruments. Values of standard errors are given in parenthesis. Definitions of variables are given in Table $1 .{ }^{* * *}$, and ${ }^{*}$ shows the level of significance at $1 \%, 5 \%$, and $10 \%$ 
$10 \%$, which supports the validity of the model. Consistent with prior results, the coefficients of the lagged value of investment are positive and significant across all columns and, hence, support our decision to choose a dynamic model for the purpose of estimation.

The coefficients of the lagged value of leverage $\left(L E V_{t-1}\right)$, found in columns (1) to (4), are $-0.0157,-0.0673,-0.0205$ and -0.0718 , respectively, and are all negative and significant. The coefficients of the lagged value of growth $\left(G T H_{t-1}\right)$ in columns (1) and (3) are 0.0096 and 0.0093 , which are positive and significant. The coefficients of the lagged value of interaction term of leverage and growth $\left(L E V_{t-1}{ }^{*} G T H_{t-1}\right)$ in columns (2) and (4) are 0.0217 and 0.0217, which are positive and significant. Overall, these findings are consistent with our main results.

Table 9 reports the findings of the investment equation with an alternative proxy of investment for high-growth and low-growth firms. Columns (1) and (4) report the results of the baseline investment equation with an alternative proxy of investment. Columns (3) and (5) report the results of DIFF GMM and SYS GMM for the high-growth firms, and columns (2) and (6) report the results of DIFF GMM and SYS GMM for the low-growth firms. The Sargan test's $p$-value and $A R(2)$ are above $10 \%$, findings which support the validity of the model. Consistent with prior studies, the coefficients of the lagged value of investment across all columns are positive and significant and, hence, support our decision to choose a dynamic model for the purpose of estimation.

The coefficients of the lagged value of growth $\left(G T H_{t-1}\right)$ in columns (1) and (4) are 0.0096 and 0.0093 , respectively, which are positive and significant. The coefficients of the lagged value of interaction of leverage and the high-growth dummy $\left(L E V_{t-1}{ }^{*} H G T H_{t-1}\right)$ in columns (2) and (5) are 0.0247 and 0.0256, respectively, which are positive and significant. The coefficients of the lagged value of the interaction term of leverage and the low-growth dummy $\left(L E V_{t-1}{ }^{*} L G T H_{t-1}\right)$ in columns (3) and (6) are -0.0225 and -0.0228 , respectively; both coefficients are negative and significant. These findings are consistent with our main results.

Table 10 reports the findings of the investment equation with an alternative proxy of investment for SOEs and NSOEs. The results of DIFF GMM for SOEs are reported in columns (1) and (2) and results of DIFF GMM for NSOEs are reported in columns (3) and (4). The $p$-value of both the Sargan test and $A R(2)$ are above 10\%, which supports the validity of the model. Consistent with prior results, the coefficients of the lagged value of investment are positive and significant across all columns and, hence, support our decision to choose a dynamic model for the purpose of estimation.

The coefficients of the lagged value of leverage $\left(L E V_{t-1}\right)$, found in columns (1) to (4), are $-0.0037,-0.0627,-0.0246$ and -0.0766 , which are all negative and significant. The coefficient of the lagged value of growth $\left(G T H_{t-1}\right)$ in columns (1) and (3) are 0.0140 and 0.00847 ; both are positive and significant. Furthermore, the coefficients of the lagged value of the interaction term of leverage and growth $\left(L E V_{t-1}{ }^{*} G T H_{t-1}\right)$ in columns (2) and (4) are 0.0284 and 0.0193 , and both coefficients are positive and significant. Overall, these findings are consistent with our main results.

Table 11 reports the findings of the investment equation with an alternative proxy of investment for high-growth and low-growth firms in SOEs and NSOEs, the analysis for which we use DIFF GMM. Columns (1) and (4) report the results of DIFF GMM for the baseline investment equation with an alternative proxy of investment. The results 
Table 9 Findings of Investment equation with an alternative proxy of investment for high growth and low growth firms

\begin{tabular}{|c|c|c|c|c|c|c|}
\hline \multirow[b]{4}{*}{ Variables } & \multicolumn{6}{|c|}{ Dependent Variable: INVST2 (alternative proxy of investment) } \\
\hline & & High Growth & Low Growth & & High Growth & Low Growth \\
\hline & $(1)$ & $(2)$ & (3) & $(4)$ & $(5)$ & $(6)$ \\
\hline & \multicolumn{3}{|l|}{ DIFF GMM } & \multicolumn{3}{|l|}{ SYS GMM } \\
\hline \multirow[t]{2}{*}{ INVST2 $_{t-1}$} & $0.113^{* * *}$ & $0.117^{* * *}$ & $0.119 * * *$ & $0.0982^{* * *}$ & $0.102^{* * *}$ & $0.104^{* * *}$ \\
\hline & $(0.0208)$ & $(0.0206)$ & $(0.0206)$ & $(0.0194)$ & $(0.0192)$ & $(0.0192)$ \\
\hline \multirow[t]{2}{*}{$L E V_{t-1}$} & -0.0157 & -0.0226 & -0.0247 & $-0.0205^{*}$ & $-0.0268^{*}$ & $-0.0291^{*}$ \\
\hline & $(0.0158)$ & $(0.0159)$ & $(0.0161)$ & $(0.0153)$ & $(0.0155)$ & $(0.0157)$ \\
\hline \multirow[t]{2}{*}{$G T H_{t-1}$} & $0.00965^{* * *}$ & & & $0.00938^{* * *}$ & & \\
\hline & $(0.00137)$ & & & $(0.00134)$ & & \\
\hline \multirow[t]{2}{*}{$L E V_{t-1} * H G T H_{t-1}$} & & $0.0247^{* * *}$ & & & $0.0256^{* * *}$ & \\
\hline & & $(0.00465)$ & & & $(0.00456)$ & \\
\hline \multirow[t]{2}{*}{ LEV $_{t-1 *}$ LGTH $_{t-1}$} & & & $-0.0225^{* * *}$ & & & $-0.0228^{* * *}$ \\
\hline & & & $(0.00450)$ & & & $(0.00440)$ \\
\hline \multirow[t]{2}{*}{$R O A_{t-1}$} & $-0.0911^{* * *}$ & $-0.0904^{* * *}$ & $-0.0924^{* * *}$ & $-0.0953^{* * *}$ & $-0.0938^{* * *}$ & $-0.0959^{* * *}$ \\
\hline & $(0.0283)$ & $(0.0291)$ & $(0.0290)$ & $(0.0278)$ & $(0.0286)$ & $(0.0286)$ \\
\hline \multirow[t]{2}{*}{$T G_{t-1}$} & $-0.686^{* * *}$ & $-0.679^{* * *}$ & $-0.682^{* * *}$ & $-0.663^{* * *}$ & $-0.655^{* * *}$ & $-0.658^{* * *}$ \\
\hline & $(0.0250)$ & $(0.0258)$ & $(0.0257)$ & $(0.0234)$ & $(0.0240)$ & (0.0239) \\
\hline \multirow[t]{2}{*}{ CFLOW $_{t-1}$} & $0.0570^{* * *}$ & $0.0629^{* * *}$ & $0.0620^{* * *}$ & $0.0546^{* * *}$ & $0.0606^{* * *}$ & $0.0598^{* * *}$ \\
\hline & $(0.0122)$ & $(0.0123)$ & $(0.0123)$ & $(0.0120)$ & $(0.0121)$ & $(0.0121)$ \\
\hline \multirow[t]{2}{*}{$\mathrm{CASH}_{t-1}$} & $-0.132^{* * *}$ & $-0.134^{* * *}$ & $-0.137^{* * *}$ & $-0.130^{* * *}$ & $-0.131^{* * *}$ & $-0.135^{* * *}$ \\
\hline & $(0.0181)$ & $(0.0183)$ & $(0.0183)$ & $(0.0176)$ & $(0.0178)$ & (0.0178) \\
\hline \multirow[t]{2}{*}{$B S I Z E_{t-1}$} & -0.00132 & -0.00128 & -0.00129 & -0.00166 & -0.00156 & -0.00157 \\
\hline & $(0.00115)$ & $(0.00115)$ & $(0.00115)$ & $(0.00112)$ & $(0.00112)$ & $(0.00112)$ \\
\hline \multirow[t]{2}{*}{ CEODUA $_{t-1}$} & -0.00147 & -0.00145 & -0.00156 & -0.000950 & -0.00108 & -0.00123 \\
\hline & $(0.00343)$ & $(0.00343)$ & $(0.00344)$ & $(0.00335)$ & $(0.00335)$ & $(0.00336)$ \\
\hline \multirow[t]{2}{*}{ INDBOARD $_{t-1}$} & -0.00885 & -0.00981 & -0.0101 & -0.0115 & -0.0126 & -0.0127 \\
\hline & $(0.0267)$ & $(0.0270)$ & $(0.0270)$ & $(0.0264)$ & $(0.0267)$ & $(0.0267)$ \\
\hline \multirow[t]{2}{*}{ Constant } & $0.228^{* * *}$ & $0.238^{* * *}$ & $0.258^{* * *}$ & $0.227^{* * *}$ & $0.236^{* * *}$ & $0.258^{* * *}$ \\
\hline & $(0.0219)$ & $(0.0217)$ & $(0.0218)$ & $(0.0214)$ & $(0.0211)$ & $(0.0213)$ \\
\hline Year & Yes & Yes & Yes & Yes & Yes & Yes \\
\hline Observations & 5954 & 5954 & 5954 & 7684 & 7684 & 7684 \\
\hline$A R(1)$ & $-12.11^{* * *}$ & $-12.26^{* * *}$ & $-12.28^{* * *}$ & $-12.2^{* * *}$ & $-12.32^{* * *}$ & $-12.34^{* * *}$ \\
\hline$A R(2)$ & 0.12 & -0.029 & -0.015 & -0.52 & -0.66 & -0.63 \\
\hline Sargan (p-value) & 0.33 & 0.12 & 0.23 & 0.16 & 0.067 & 0.13 \\
\hline
\end{tabular}

Note. This Table reports findings of investment equation with an alternative proxy of investment in high-growth and low-growth firms. Arrellano-Bond tests are represented by AR (1) \& AR (2) for serial correlation in residuals. Sargan ( $p$ value) refers to the $p$-value of Sargan test to check the over-identification of instruments. Values of standard errors are given in parenthesis. Definitions of variables are given in Table 1. ***, and * shows the level of significance at $1 \%, 5 \%$, and $10 \%$

of DIFF GMM are reported in Columns (2) and (3) for high-growth and low-growth firms in SOEs, and columns (5) and (6) report results of DIFF GMM for high-growth and low-growth firms in NSOEs. The $p$-value of both the Sargan test and $A R(2)$ are above $10 \%$, which supports the validity of the model. Consistent with prior results, the coefficients of the lagged value of investment are positive and significant across all 
Table 10 Findings of Investment equation with an alternative proxy of investment in SOEs and NSOES

\begin{tabular}{|c|c|c|c|c|}
\hline \multirow[b]{4}{*}{ Variables } & \multicolumn{4}{|c|}{ Dependent Variable: INVST2 (alternative proxy of investment) } \\
\hline & \multicolumn{2}{|l|}{ SOES } & \multicolumn{2}{|l|}{ NSOES } \\
\hline & (1) & (2) & (3) & (4) \\
\hline & DIFF GMM & & & \\
\hline \multirow[t]{2}{*}{$\overline{\text { INVST2 }_{t-1}}$} & $0.0650^{* * *}$ & $0.0681^{* * *}$ & 0.0374 & $0.0412^{*}$ \\
\hline & $(0.0212)$ & $(0.0212)$ & $(0.0235)$ & $(0.0236)$ \\
\hline \multirow[t]{2}{*}{$L E V_{t-1}$} & $-0.00373^{*}$ & $-0.0627^{* * *}$ & $-0.0246^{*}$ & $-0.0766^{* * *}$ \\
\hline & $(0.0242)$ & $(0.0219)$ & $(0.0190)$ & $(0.0202)$ \\
\hline \multirow[t]{2}{*}{$G T H_{t-1}$} & $0.0140^{* * *}$ & & $0.00847^{* * *}$ & \\
\hline & $(0.00226)$ & & $(0.00164)$ & \\
\hline \multirow[t]{2}{*}{$L E V_{t-1} * G T H_{t-1}$} & & $0.0284^{* * *}$ & & $0.0193^{* * *}$ \\
\hline & & $(0.00514)$ & & $(0.00321)$ \\
\hline \multirow[t]{2}{*}{$R O A_{t-1}$} & -0.0634 & $-0.0676^{*}$ & $-0.116^{* * *}$ & $-0.114^{* * *}$ \\
\hline & $(0.0393)$ & $(0.0384)$ & $(0.0366)$ & $(0.0375)$ \\
\hline \multirow[t]{2}{*}{$T G_{t-1}$} & $-0.690^{* * *}$ & $-0.692^{* * *}$ & $-0.710^{* * *}$ & $-0.708^{* * *}$ \\
\hline & $(0.0294)$ & $(0.0289)$ & $(0.0382)$ & $(0.0385)$ \\
\hline \multirow[t]{2}{*}{ CFLOW $_{t-1}$} & $0.0560^{* * *}$ & $0.0537^{* * *}$ & $0.0571^{* * *}$ & $0.0573^{* * *}$ \\
\hline & $(0.0168)$ & $(0.0169)$ & $(0.0165)$ & $(0.0164)$ \\
\hline \multirow[t]{2}{*}{$\mathrm{CASH}_{t-1}$} & $-0.145^{* * *}$ & $-0.141^{* * *}$ & $-0.128^{* * *}$ & $-0.128^{* * *}$ \\
\hline & $(0.0275)$ & $(0.0275)$ & $(0.0216)$ & $(0.0213)$ \\
\hline \multirow[t]{2}{*}{$B S I Z E_{t-1}$} & -0.000971 & -0.00110 & -0.00132 & -0.00125 \\
\hline & $(0.00159)$ & (0.00158) & $(0.00161)$ & $(0.00164)$ \\
\hline \multirow[t]{2}{*}{$C E O D \cup A_{t-1}$} & 0.000985 & 0.000172 & -0.00358 & -0.00306 \\
\hline & $(0.00555)$ & $(0.00557)$ & $(0.00390)$ & $(0.00388)$ \\
\hline \multirow[t]{2}{*}{ INDBOARD $_{t-1}$} & 0.000962 & -0.00717 & -0.00770 & -0.0103 \\
\hline & $(0.0351)$ & $(0.0346)$ & $(0.0371)$ & $(0.0371)$ \\
\hline \multirow[t]{2}{*}{ Constant } & $0.206^{* * *}$ & $0.260^{* * *}$ & $0.220^{* * *}$ & $0.244^{* * *}$ \\
\hline & $(0.0317)$ & $(0.0297)$ & $(0.0299)$ & $(0.0281)$ \\
\hline Year & Yes & Yes & Yes & Yes \\
\hline Observations & 3401 & 3401 & 2553 & 2553 \\
\hline$A R(1)$ & $-9.12^{* * *}$ & $-9.00^{* * *}$ & $-7.93^{* * *}$ & -7.88 \\
\hline$A R(2)$ & 0.43 & 0.56 & -0.91 & -0.85 \\
\hline Sargan ( $p$-value) & 0.52 & 0.46 & 0.55 & 0.59 \\
\hline
\end{tabular}

Note. This table reports findings of investment equation with an alternative proxy of investment in SOEs and NSOEs. Arrellano-Bond tests are represented by AR (1) \& AR (2) for serial correlation in residuals. Sargan ( $p$-value) refers to the $p$ value of Sargan test to check the over-identification of instruments. Values of standard errors are given in parenthesis. Definitions of variables are given in Table 1. ${ }^{* * *}$, and ${ }^{*}$ shows the level of significance at $1 \%, 5 \%$, and $10 \%$

columns and, hence, support our decision to choose a dynamic model for the purpose of estimation.

The coefficients of the lagged value of leverage $\left(L E V_{t-1}\right)$, found in columns (4) to (6), are $-0.0246,-0.0336$ and -0.0356 , which are positive and significant. The coefficients of the lagged value of growth $\left(G T H_{t-1}\right)$ in columns (1) and (4) are 0.0140 and 0.0084 , respectively, which are positive and significant. The coefficients of the lagged value of the interaction term for leverage and the high-growth dummy $\left(L E V_{t-1} * H G T H_{t-1}\right)$ in columns (2) and (5) are 0.0275 and 0.0187 , respectively, which are positive and significant. 
Table 11 Findings of Investment equation with an alternative proxy of investment for high growth and low growth firms in SOEs and NSOEs

\begin{tabular}{|c|c|c|c|c|c|c|}
\hline \multirow[b]{5}{*}{ Variables } & \multicolumn{6}{|c|}{ Dependent Variable: INVST2 (alternative proxy of investment) } \\
\hline & (1) & $(2)$ & (3) & $(4)$ & (5) & (6) \\
\hline & & High growth & Low growth & & High growth & Low growth \\
\hline & \multicolumn{3}{|l|}{ SOEs } & \multicolumn{3}{|l|}{ NSOES } \\
\hline & DIFF GMM & & & & & \\
\hline \multirow[t]{2}{*}{ INVST2 } & $0.130^{* * *}$ & $0.137^{* * *}$ & $0.139 * * *$ & $0.0740^{* *}$ & $0.0817^{* * *}$ & $0.0823^{* * *}$ \\
\hline & $(0.0254)$ & $(0.0252)$ & $(0.0253)$ & $(0.0305)$ & $(0.0300)$ & $(0.0300)$ \\
\hline \multirow[t]{2}{*}{$L E V_{t-1}$} & -0.00373 & -0.0148 & -0.0147 & $-0.0246^{*}$ & $-0.0336^{*}$ & $-0.0356^{*}$ \\
\hline & $(0.0242)$ & $(0.0242)$ & $(0.0245)$ & $(0.0190)$ & $(0.0192)$ & (0.0195) \\
\hline \multirow[t]{2}{*}{$G T H_{t-1}$} & $0.0140^{* * *}$ & & & $0.00847^{* * *}$ & & \\
\hline & $(0.00226)$ & & & $(0.00164)$ & & \\
\hline \multirow{2}{*}{$L E V_{t-1}{ }^{*} H G T H_{t-1}$} & & $0.0275^{* * *}$ & & & $0.0187^{* * *}$ & \\
\hline & & $(0.00706)$ & & & $(0.00525)$ & \\
\hline \multirow[t]{2}{*}{$L E V_{t-1}{ }^{*} L G T H_{t-1}$} & & & $-0.0242^{* * *}$ & & & $-0.0193^{* * *}$ \\
\hline & & & $(0.00658)$ & & & $(0.00531)$ \\
\hline \multirow[t]{2}{*}{$R O A_{t-1}$} & -0.0634 & -0.0622 & -0.0637 & $-0.116^{* * *}$ & $-0.120^{* * *}$ & $-0.121^{* * *}$ \\
\hline & $(0.0393)$ & $(0.0414)$ & $(0.0413)$ & $(0.0366)$ & $(0.0367)$ & $(0.0367)$ \\
\hline \multirow[t]{2}{*}{$T G_{t-1}$} & $-0.690^{* * *}$ & $-0.678^{* * *}$ & $-0.681^{* * *}$ & $-0.710^{* * *}$ & $-0.702^{* * *}$ & $-0.705^{* * *}$ \\
\hline & $(0.0294)$ & $(0.0302)$ & $(0.0301)$ & $(0.0382)$ & $(0.0395)$ & (0.0393) \\
\hline \multirow[t]{2}{*}{$C F L O W_{t-1}$} & $0.0560^{* * *}$ & $0.0606^{* * *}$ & $0.0599 * * *$ & $0.0571^{* * *}$ & $0.0650^{* * *}$ & $0.0640^{* * *}$ \\
\hline & $(0.0168)$ & $(0.0173)$ & $(0.0173)$ & $(0.0165)$ & $(0.0162)$ & $(0.0162)$ \\
\hline \multirow[t]{2}{*}{$\mathrm{CASH}_{t-1}$} & $-0.145^{* * *}$ & $-0.141^{* * *}$ & $-0.144^{* * *}$ & $-0.128^{* * *}$ & $-0.133^{* * *}$ & $-0.136^{* * *}$ \\
\hline & $(0.0275)$ & $(0.0285)$ & $(0.0284)$ & $(0.0216)$ & $(0.0214)$ & $(0.0215)$ \\
\hline \multirow[t]{2}{*}{$B S I Z E_{t-1}$} & -0.000971 & -0.000782 & -0.000774 & -0.00132 & -0.00123 & -0.00124 \\
\hline & $(0.00159)$ & $(0.00160)$ & $(0.00160)$ & $(0.00161)$ & $(0.00159)$ & $(0.00160)$ \\
\hline \multirow[t]{2}{*}{$C E O D \cup A_{t-1}$} & 0.000985 & 0.00131 & 0.00150 & -0.00358 & -0.00384 & -0.00404 \\
\hline & $(0.00555)$ & $(0.00544)$ & $(0.00548)$ & $(0.00390)$ & $(0.00397)$ & $(0.00395)$ \\
\hline \multirow[t]{2}{*}{ INDBOARD $_{t-1}$} & 0.000962 & 0.00383 & 0.00221 & -0.00770 & -0.00810 & -0.00699 \\
\hline & $(0.0351)$ & $(0.0358)$ & $(0.0358)$ & $(0.0371)$ & $(0.0376)$ & $(0.0376)$ \\
\hline \multirow[t]{2}{*}{ Constant } & $0.206^{* * *}$ & $0.219^{* * *}$ & $0.235^{* * *}$ & $0.220^{* * *}$ & $0.230^{* * *}$ & $0.242^{* * *}$ \\
\hline & $(0.0317)$ & $(0.0314)$ & $(0.0316)$ & $(0.0299)$ & $(0.0286)$ & $(0.0285)$ \\
\hline Year & Yes & Yes & Yes & Yes & Yes & Yes \\
\hline Observations & 3401 & 3401 & 3401 & 2553 & 2553 & 2553 \\
\hline$A R(1)$ & $-9.123^{* * *}$ & $-9.353^{* * *}$ & $-9.337^{* * *}$ & $-7.933^{* * *}$ & $-8.002^{* * *}$ & $-8.052^{* * *}$ \\
\hline$A R(2)$ & 0.430 & 0.354 & 0.338 & -0.916 & -1.104 & -1.080 \\
\hline Sargan ( $p$-value) & 0.52 & 0.324 & 0.405 & 0.751 & 0.687 & 0.777 \\
\hline
\end{tabular}

Note. This table reports findings of investment equation with an alternative proxy of investment for-high growth and low-growth firms in SOEs and NSOEs. Arrellano-Bond tests are denoted by AR (1) \& AR (2) for serial correlation in residuals. Sargan ( $p$-value) refers to the $p$-value of Sargan test to check the over-identification of instruments. Values of standard errors are given in parenthesis. Definitions of variables are given in Table $1 .{ }^{* * *},{ }^{*}$, and ${ }^{*}$ shows the level of significance at $1 \%, 5 \%$, and $10 \%$

The coefficients of the lagged value of the interaction term of leverage and growth for low-growth firms $\left(L E V_{t-1}{ }^{*} L G T H_{t-1}\right)$ in columns (3) and (6) are -0.0242 and 0.0193 , respectively, which are negative and significant. These findings are consistent with our prior results. 
Results discussion

Leverage and investment

The results from this study suggest that leverage has a negative association with investment. The findings remain consistent for SOEs and NSOEs and also in consideration of alternative proxy variables for investment. The results provide support for Hypothesis 1: that is, leverage is negatively associated with the investment, and therefore we can accept Hypothesis 1.

The empirical evidence supports the argument that, as a result of the conflict of interest between shareholders and managers, managers may invest available cash flows in projects having a low return or negative NPVs and thus leverage can play a disciplining and monitoring role to reduce overinvestment (Jensen 1986).

\section{Growth and investment}

The results of this study also suggest that growth has a positive association with investment. The findings remain consistent for SOEs and NSOEs and in consideration of alternative proxy variables for investment. The findings support Hypothesis 2: that is, growth is positively associated with the investment, and therefore we can accept Hypothesis 2. One possible reason for this result is that efficient financing decisions help Chinese firms exploit valuable growth opportunities (Myers 1977).

\section{Moderating effect of leverage on the relationship between growth and investment}

The results suggest that the interaction term of leverage and growth has a significant and positive relationship with investment. These findings remain valid for SOEs and NSOEs, even after considering alternative proxy variables for investment. The findings are also consistent with Hypothesis 3: that is, leverage enhances the positive impact of growth on investment, and therefore we can accept Hypothesis 3.

One possible reason for this result is that reducing the debt overhang problem sufficiently helps Chinese firms make the best use of leverage, which can ultimately help them to take more valuable growth opportunities. Our findings support the argument made by previous research (Childs et al. 2005; Coad and Srhoj 2019; Dang 2011) that the short-term debt strategy allows firms to take more growth opportunities, which results in an increase in investment.

Moderating effect of leverage on the relationship between growth and investment for highgrowth and low-growth firms

The results suggest that the interaction term of leverage and growth has a significant and positive relationship with investment for high-growth firms and a negative relationship for low-growth firms. These findings remain consistent for SOEs and NSOEs, even in consideration of alternative proxy variables for investment. The empirical evidence is consistent with Hypothesis 4: that is, leverage increases the positive impact of growth on investment for high-growth firms and weakens the impact of growth on investment for low-growth firms, and therefore we can accept Hypothesis 4.

Our findings support the argument that leverage plays an advisory and monitoring role for low-growth firms, restricting them from investing in low-growth opportunities (Jensen 1986). Further findings suggest that leverage encourages high-growth firms to 
invest in high-growth opportunities. Therefore, leverage increases the impact of growth on subsequent investment for firms that have high-growth opportunities, and it reduces the impact of growth on subsequent investment for firms whose growth opportunities are not well known or sufficiently valuable.

\section{Conclusion}

This study examines how a reliance on short-term debt helps Chinese listed firms make efficient investment decisions and reduce problems inherent to overinvestment for lowgrowth firms. Based on the agency cost theory, we develop a unified framework that models the theoretical links between growth, leverage and investment.

We use DIFF GMM and SYS GMM to control for endogeneity and dynamics in the execution of investment decisions. The GMM dynamic model takes the first difference of all the variables of a dynamic equation and, being robust to heteroscedasticity and cross-correlation, it overcomes all the non-linear restrictions (Arellano and Bond 1991; Blundell and Bond 1998).

This study provides several contributions to the literature. We investigate the relationship between leverage and subsequent investments, and find that leverage is in fact negatively associated with subsequent investments. The results further reveal that leverage reduces the positive impact of growth on subsequent investments for low-growth firms. The findings also suggest that leverage plays a monitoring and advisory role and restricting managers from investing in projects with low returns or negative NPVs. Moreover, we investigate the relationship between growth and subsequent investments, finding shows that growth has have a positive and significant relationship with subsequent investment. We also find that leverage enhances the positive impact of growth on subsequent investment. In an additional analysis, we also find that leverage enhances the positive impact of growth on investment for high-growth firms. These findings remain consistent across different types of ownership, i.e., SOEs and NSOEs, and by considering alternative proxies for growth and investment.

The findings of the study also provide empirical support to the agency cost theory in the Chinese context, for example that leverage, which comprises a higher proportion of short-term debt, helps Chinese firms exploit valuable growth opportunities, and that leverage reduces overinvestment problem and restricts firms from investing in lowgrowth opportunities. Consequently, flexible financing decisions reduce the agency conflicts among creditors, managers and shareholders.

Overall, the findings suggest that a debt policy that focuses on higher proportions of short-term debt may help firms make better financing decisions in view of valuable forecasted growth opportunities, reduce the potential of underinvestment problem and help them make more efficient investment decisions. The results of this study also imply that short-term debt can play an important role in mitigating agency conflicts and therefore improve the probability that firms will take advantage of available investment opportunities. Thus, we suggest that shareholders should consider short-term debt in order to mitigate the risks inherent to debt overhang, and restrict the opportunistic behavior of the company's managers, which may likewise lead to more efficient investment decisions.

We acknowledge, however, that there are some limitations to this study, which may be addressed by future research. First, the study does not investigate the impact of 
financing decisions on investment decisions of small to medium-sized enterprises. Second, due to the limited availability of data, the study does not examine how debt covenants play a role in investment decisions. Future research can address the limitations of the study, first by investigating the role of debt covenants in investment decisions and, second, by replicating this study and examining whether a similar phenomenon occurs at different organizational levels and in different contexts.

\section{Acknowledgements}

We are grateful to the anonymous reviewers for their constructive comments on the earlier version of this paper.

\section{Authors' contributions}

Bhat contributes in the design, analysis and in writing the draft, Ding contributes in result discussion and provides quality inputs, and Jebran contributes in data analysis. The authors read and approved the final manuscript.

\section{Funding}

This article is supported by Liaoning provincial key project "Research on the development of digitalized rural inclusive financial service systems in Liaoning province" (Project number, LN2020Z03).

\section{Availability of data and materials}

We extracted data from Chinese database CSMAR, and data is available on reasonable request.

\section{Competing interests}

The authors declare that they have no competing interests.

\section{Author details}

${ }^{1}$ School of Finance, Dongbei University of Finance and Economics, Dalian, China. ${ }^{2}$ School of Business Administration, Dongbei University of Finance and Economics, Dalian, China.

Received: 9 October 2019 Accepted: 18 August 2020

Published online: 09 October 2020

\section{References}

Ahn S, Denis DJ, Denis DK (2006) Leverage and investment in diversified firms. J Financ Econ 79(2):317-337

Aivazian VA, Ge Y, Qiu J (2005a) Debt maturity structure and firm investment. Financ Manag 34(4):107-119

Aivazian VA, Ge Y, Qiu J (2005b) The impact of leverage on firm investment: Canadian evidence. J Corp Finan 11(1):277-291

Arellano M, Bond S (1991) Some tests of specification for panel data: Monte Carlo evidence and an application to employment equations. Rev Econ Stud 58(2):277-297

Blundell R, Bond S (1998) Initial conditions and moment restrictions in dynamic panel data models. J Econ 87(1):115-143

Brown JR, Petersen BC (2009) Why has the investment-cash flow sensitivity declined so sharply? Rising R\&D and equity market developments. J Bank Financ 33(5):971-984

Cai K, Fairchild R, Guney Y (2008) Debt maturity structure of Chinese companies. Pac Basin Financ J 16(3):268-297

Chen G, Firth M, Gao DN, Rui OM (2006) Ownership structure, corporate governance, and fraud: evidence from China. J Corp Finan 12(3):424-448

Childs PD, Mauer DC, Ott SH (2005) Interactions of corporate financing and investment decisions: the effects of agency conflicts. J Financ Econ 76(3):667-690

Chow CKW, Fung MKY (1998) Ownership structure, lending bias, and liquidity constraints: evidence from Shanghai's manufacturing sector. J Comp Econ 26(2):301-316

Cleary S (1999) The relationship between firm investment and financial status. J Financ 54(2):673-692

Coad A, Srhoj SJSBE (2019) Catching Gazelles with a Lasso: Big data techniques for the prediction of high-growth firms, pp $1-25$

Coles JL, Daniel ND, Naveen L (2006) Managerial incentives and risk-taking. J Financ Econ 79(2):431-468

Dang VA (2011) Leverage, debt maturity and firm investment: an empirical analysis. J Bus Financ Acc 38(1-2):225-258

Danso A, Adomako S (2014) The financing behaviour of firms and financial crisis. Manag Financ 40(12):1159-1174

Denis DJ, Denis DK (1993) Managerial discretion, organizational structure, and corporate performance: A study of leveraged recapitalizations. J Account Econ 16(1-3):209-236

Duchin R, Ozbas O, Sensoy BA (2010) Costly external finance, corporate investment, and the subprime mortgage credit crisis. J Financ Econ 97(3):418-435

Fan DKK, Lau C-M, Young M (2007) Is China's corporate governance beginning to come of age? The case of CEO turnover. Pac Basin Financ J 15(2):105-120

Fan JP, Huang J, Oberholzer-Gee F, Zhao M (2017) Bureaucrats as managers and their roles in corporate diversification. J Corp Finan, 63. https://www.sciencedirect.com/science/article/pii/S0929119916301924?via\%3Dihub.

Fazzari S, Hubbard RG, Petersen BC (1987) Financing constraints and corporate investment: National Bureau of economic research Cambridge, Mass, USA, w2387. https://www.nber.org/papers/w2387.

Firth M, Malatesta PH, Xin Q, Xu L (2012) Corporate investment, government control, and financing channels: evidence from China's listed companies. J Corp Finan 18(3):433-450

Gertler M, Gilchrist S (1994) Monetary policy, business cycles, and the behavior of small manufacturing firms. Q J Econ 109(2): 309-340 
Guariglia A (2008) Internal financial constraints, external financial constraints, and investment choice: evidence from a panel of UK firms. J Bank Financ 32(9):1795-1809

Guariglia A, Liu X, Song L (2011) Internal finance and growth: microeconometric evidence on Chinese firms. J Dev Econ 96(1): 79-94

Gul FA (1999) Government share ownership, investment opportunity set and corporate policy choices in China. Pac Basin Financ J 7(2):157-172

Héricourt J, Poncet S (2009) FDI and credit constraints: firm-level evidence from China. Econ Syst 33(1):1-21

Hoshi T, Kashyap A, Scharfstein D (1991) Corporate structure, liquidity, and investment: evidence from Japanese industrial groups. Q J Econ 106(1):33-60

Howell, A. (2020). Agglomeration, absorptive capacity and knowledge governance: implications for public-private firm innovation in China. Reg Stud 54(8):1069-1083.

Jensen M (1986) Agency costs of free cash flow, corporate finance, and takeovers. Am Econ Rev 76(2):323-329

Jiang F, Jiang Z, Kim KA (2017) Capital markets, financial institutions, and corporate finance in China. J Corp Finan

Lam S-S, Du J (2004) Information asymmetry and estimation risk: preliminary evidence from Chinese equity markets. Pac Basin Financ J 12(3):311-331

Lamont O (1997) Cash flow and investment: evidence from internal capital markets. J Financ 52(1):83-109

Lang L, Ofek E, Stulz R (1996) Leverage, investment, and firm growth. J Financ Econ 40(1):3-29

Lemmon ML, Zender JF (2019) Asymmetric information, debt capacity, and capital structure. J Financ Quant Anal 54(1):31-59

Lin C, Su D (2008) Industrial diversification, partial privatization and firm valuation: evidence from publicly listed firms in China. J Corp Finan 14(4):405-417

Modigliani F, Miller MH (1958) The cost of capital, corporation finance and the theory of investment. Am Econ Rev 48(3):261297

Myers SC (1977) Determinants of corporate borrowing. J Financ Econ 5(2):147-175

Poncet S, Steingress W, Vandenbussche H (2010) Financial constraints in China: firm-level evidence. China Econ Rev 21(3): $411-422$

Rehman A-U, Wang M, Mirza SS (2017) How do Chinese firms adjust their financial leverage: an empirical investigation using multiple GMM models. China Finance Econ Rev 5(1):8

Scandizzo PL (2004) Financing technology: an assessment of theory and practice

Stulz R (1990) Managerial discretion and optimal financing policies. J Financ Econ 26(1):3-27

Su LD (2010) Ownership structure, corporate diversification and capital structure: evidence from China's publicly listed firms. Manag Decis 48(2):314-339

Wen F, Xu L, Ouyang G, Kou G (2019) Retail investor attention and stock price crash risk: evidence from China. Int Rev Financ Anal 65:101376

Yang X, Han L, Li W, Yin X, Tian L (2017) Monetary policy, cash holding and corporate investment: evidence from China. China Econ Rev 46(Supplement C):110-122

Yu M, Ashton JK (2015) Board leadership structure for Chinese public listed companies. China Econ Rev 34:236-248

\section{Publisher's Note}

Springer Nature remains neutral with regard to jurisdictional claims in published maps and institutional affiliations.

\section{Submit your manuscript to a SpringerOpen ${ }^{\circ}$ journal and benefit from:}

- Convenient online submission

- Rigorous peer review

- Open access: articles freely available online

High visibility within the field

- Retaining the copyright to your article

Submit your next manuscript at $\boldsymbol{\Delta}$ springeropen.com 